\title{
Carboxylic acids and carbonyl compounds in southern California clouds and fogs
}

\author{
By J. WILLIAM MUNGER, JEFF COLLETT, JR., BRUCE C. DAUBE, JR. and \\ MICHAEL R. HOFFMANN, Environmental Engineering Science, W. M. Keck Laboratories, \\ 138-78, California Institute of Technology, Pasadena, CA 91125, USA
}

(Manuscript received 16 November 1987; in final form 1 July 1988)

\begin{abstract}
Formaldehyde, formate, and acetate have been determined in fog and cloudwater from several areas of southern California. Up to $190 \mu \mathrm{M}$ formate and acetate was seen in high $\mathrm{pH}$ fog samples from the San Joaquin Valley. Formaldehyde concentrations as high as $500 \mu \mathrm{M}$ were observed there. Organic acid concentrations were much lower at an acidic site along the margin of the valley. Fog from Riverside, CA had maximum concentrations of 1500 and $500 \mu \mathrm{M}$ formate and acetate. The highest concentrations were observed in the samples with highest pH. Formaldehyde at Riverside was as high as $380 \mu \mathrm{M}$. Average formate and acetate concentrations in intercepted stratus clouds from the Santa Barbara Channel coast and San Pedro Hill were 20-60 $\mu \mathrm{M}$ and 10-30 $\mu \mathrm{M}$, respectively. Formaldehyde concentrations in stratus clouds were $10-20 \mu \mathrm{M}$. Because the lifetime of a cloud or fog droplet is usually much longer than the characteristic time for interfacial mass transport, hydration or dissociation, droplets can be assumed to be in equilibrium with their surroundings. The product of aqueousphase concentration and liquid water content in the cloud (fog) is nearly always much less than the predicted equilibrium partial pressure. Only the high $\mathrm{pH}$ fogs from the San Joaquin Valley have the potential to deplete the gas-phase reservoir of organic acid.
\end{abstract}

\section{Introduction}

Soluble organic carbon is an important component of the atmosphere. Liljestrand and Morgan (1981) observed that organic carbon was the dominant component by mass of rainwater collected in Los Angeles, while Likens et al. (1983) established that carbonyl compounds and carboxylic acids contribute a major portion of the dissolved organic carbon in rainwater. Carboxylic acids can be the dominant source of free acidity in rainwater, particularly in remote regions where strong mineral acids are scarce (Galloway et al., 1982; Keene et al., 1983). At high $\mathrm{pH}$ the salts of carboxylic acids (e.g., $\mathrm{NH}_{4}^{+} \mathrm{COO}^{-}$) become a component of atmospheric alkalinity (Jacob et al., 1986). Carbonyls play a well known role in gas-phase photochemistry (Finlayson-Pitts and Pitts, 1986; Seinfeld, 1986). In the aqueous phase, formation of gem diols reduces their susceptibility to photolysis. However, model calculations indicate that the following reaction may be important (Chameides, 1984).

$\mathrm{CH}_{2}(\mathrm{OH})_{2}+\mathrm{OH} \cdot \stackrel{\mathrm{O}_{2}}{\longrightarrow} \mathrm{HCOOH}+\mathrm{HO}_{2} \cdot+\mathrm{H}_{2} \mathrm{O}$.

The fate of $\mathrm{HCOOH}$ formed via this reaction is $\mathrm{pH}$ dependent (Jacob, 1986). At $\mathrm{pH}>\mathrm{pK}_{\mathrm{a}}$, $\mathrm{HCOO}^{-}$is rapidly oxidized by $\mathrm{OH} \cdot$, while in acidic droplets $\mathrm{HCOOH}$ may be released to the surrounding atmosphere. In addition the formation of carbonyl-S(IV) adducts (hydroxyalkylsulfonates) may enhance S(IV) scavenging in droplets (Munger et al., 1984, 1986).

The equilibria that control partitioning of carbonyls and carboxylic acids between droplets and the surrounding air are shown in Table 1. Equilibrium constants have been measured for many environmentally important species; some important constants, however, have not been 


\section{Table 1. Generalized equilibrium reactions}

\begin{tabular}{ll}
\hline $\begin{array}{l}\text { Henry's Law } \\
\text { aldehyde } \\
\text { Henry's Law } \\
\quad \text { organic acid }\end{array}$ & $\mathrm{RCHO}_{(\mathrm{g})} \stackrel{\mathrm{H}_{\mathrm{g}}}{\rightleftharpoons} \mathrm{RCHO}_{(\mathrm{aq})}$ \\
Dissociation & $\mathrm{HA}_{(\mathrm{g})} \stackrel{\mathrm{H}_{\mathrm{k}}}{\rightleftharpoons} \mathrm{HA}_{(\mathrm{aq})}$ \\
Hydration & $\mathrm{HA}_{(\mathrm{aq})} \stackrel{\mathrm{K}_{\mathrm{s}}}{\rightleftharpoons} \mathrm{H}^{+}+\mathrm{A}^{-}$ \\
Sulfonate formation & $\mathrm{RCHO}_{(\mathrm{aq})} \stackrel{\mathrm{K}_{\mathrm{H}}}{\rightleftharpoons} \mathrm{RCH}(\mathrm{OH})_{2}$ \\
\hline
\end{tabular}

determined. In these cases, Taft correlations can be used to estimate values for carbonyl hydration constants and sulfonate stability constants (Betterton et al., 1988). Because the characteristic times for interfacial mass transfer and the equilibrium reactions in Table 1 are short compared to cloud droplet lifetimes, droplets should be in equilibrium with their surroundings (Schwartz and Freiberg, 1981). Raindrops, however, which are larger and fall through layers with different compositions may not achieve equilibrium with their surroundings.

Some general predictions may be made about the distribution of carbonyls and carboxylic acids in the presence of liquid water. Carbonyl solubility is primarily a function of the hydration constant. Formaldehyde is easily hydrated, but the longer chain carbonyls are not. Aldehydes with low hydration constants will be less important in the aqueous phase. Because electron withdrawing substituents adjacent to the carbonyl carbon enhance its hydration, dicarbonyls and halo-substituted acetaldehyde should have large hydration constants. The carbonyl group on ketoacids, such as pyruvic, should be strongly hydrated when the acid is protonated, but not when it is dissociated. Sulfonate stability is similarly enhanced by an adjacent electron withdrawing substituent, so it should follow the same trend as the hydration constants (Olson and Hoffmann, 1988).

The distribution of carboxylic acids between vapor and aqueous phase will be strongly $\mathrm{pH}$ dependent. At droplet $\mathrm{pH}$ values below the $\mathrm{pK}_{\mathrm{a}}$ for the acid, most of it will be present in the gas phase. When the $\mathrm{pH}$ of the droplet is above the $\mathrm{pK}_{\mathrm{a}}$, the droplet will be an efficient sink for weak acids. At $25^{\circ} \mathrm{C}$ in a cloud with liquid water content $=0.5 \mathrm{~g} \mathrm{~m}^{-3}$, formate and acetate are predicted to be found predominantly in the aqueous phase above $\simeq \mathrm{pH} 5$ and 6 , respectively. The solubility of carbonyls and carboxylic acids is increased further by low temperatures.

Combustion processes are the major source of primary aldehydes (Rogozen et al., 1984). Vegetation and combustion are thought to be direct sources of carboxylic acids (Graedel et al., 1986). Acetic and formic acid have been observed in automobile exhaust and smoke from burning biomass (Kawamura et al., 1985; Talbot et al., 1988). Bacterial metabolism produces a variety of short-chain carboxylic acids; thus decomposing organic matter (e.g., soils, manure) could be sources of carboxylic acids. Atmospheric reactions, however, are thought to be the major sources of carbonyls and carboxylic acids. A wide variety of aldehydes, ketones and substituted carbonyls are formed from the oxidation of hydrocarbons. Even non-urban areas may have a strong source of carbonyls and carboxylic acids. For example, ozonolysis of isoprene, a natural hydrocarbon emitted by vegetation, is potentially a major source of $\mathrm{HCOOH}$ (Jacob and Wofsy, 1988). Carbonyls are sensitive to photolysis and attack by oxidants. Atmospheric residence times for aldehydes are less than a day (NRC, 1981). Carboxylic acids are generally more stable; their major sink is surface deposition.

Keene and Galloway (1986) have summarized much of the recent data on $\mathrm{HCOOH}$ and $\mathrm{CH}_{3} \mathrm{OOH}$ in rainwater. However, fog and cloudwater measurements made in conjunction with gas-phase measurements are less extensive. Carlier et al. (1986) have summarized the literature on gas-phase formaldehyde. Fewer data are available on aqueous-phase formaldehyde. In this paper we present data on formaldehyde, formate and acetate concentrations in cloud and fogwater from several sites in southern California. Our objective is to establish the range of concentrations in these environments and identify differences and similarities among the various sites.

\section{Methods}

Samples have been collected from four regions of southern California (see Fig. 1) with a variety of meteorological and pollution characteristics. 


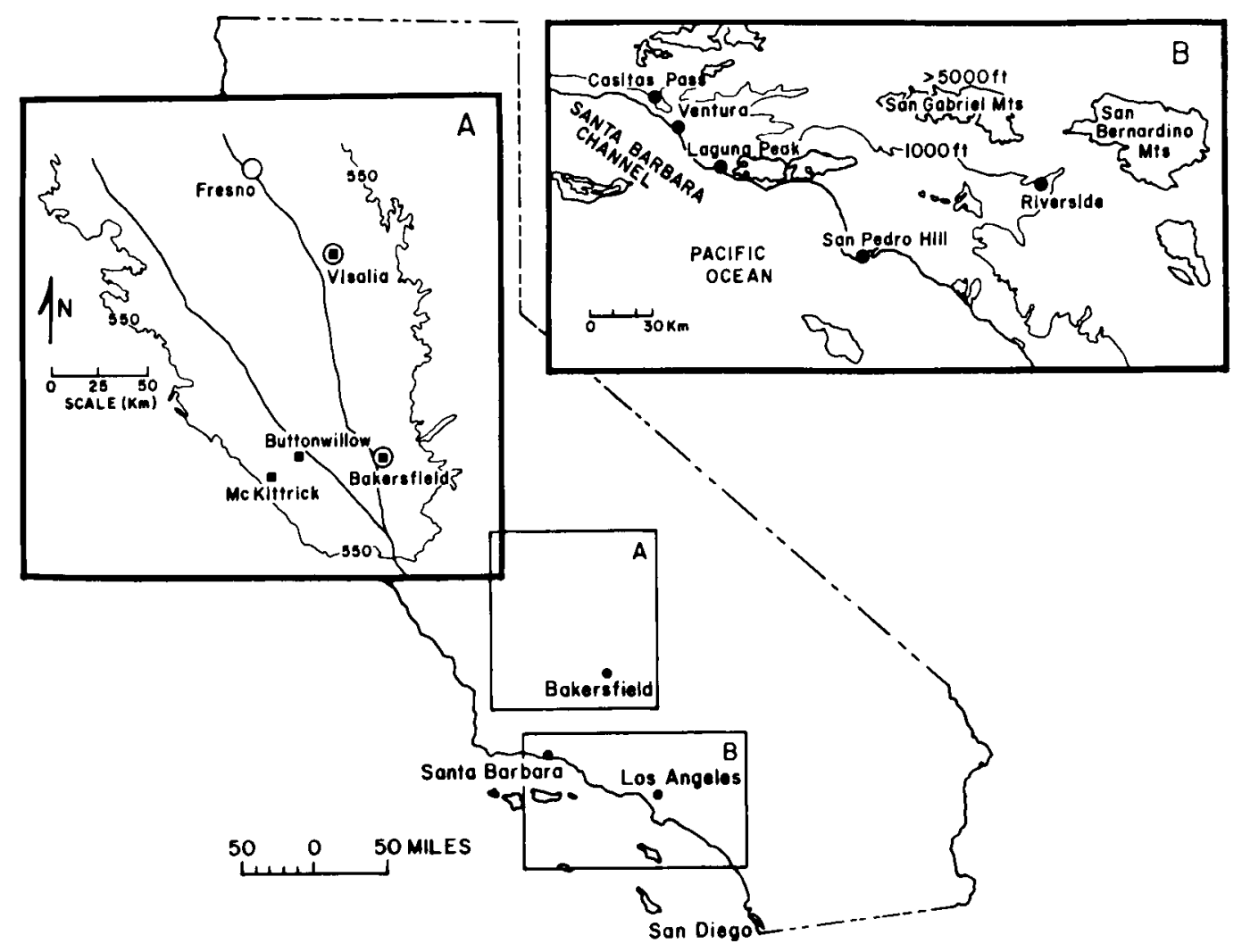

Fig. I. Inset A shows the San Joaquin Valley outlined by the $550 \mathrm{~m}$ contour. The location of sampling sites ( $\square$ ), highways $(-)$, and population centers $(O)$ are indicated. Oil fields surround McKittrick and Bakersfield, livestock feedlots are centered around Visalia and Bakersfield. Inset B shows the Los Angeles Basin and Santa Barbara Channel area with sampling sites denoted by $\bullet$.

The San Joaquin Valley (inset A of Fig. 1) is subject to persistent stagnation episodes, lasting several days at a time. These are accompanied by fog or low stratus, during the early winter months. Emissions from urban centers, oil field steam generators, animal feedlots, and agricultural burning accumulate in the stagnant air mass. Crop residues are commonly burned in the San Joaquin Valley. Although air pollution control regulations prohibit burning when the valley is not well ventilated, emissions from these fires could persist in the valley and contribute to the organic species observed in the fog. Fogwater samples were collected at four locations during the period December 1983-January 1984. Bakersfield is a major population center adjacent to the oilfields on the east side of the valley. Visalia is a small city in a predominantly agricultural area. Buttonwillow is a small town surrounded by cropland. McKittrick is located on the west slope of the valley and is surrounded by oilfields; because of its high elevation it is impacted by stratus clouds that do not affect the valley floor. Details of the sampling conditions and the inorganic ion analyses are presented elsewhere (Jacob et al., 1986). Fogwater pH values in the San Joaquin Valley range from near 3 to above 6 , depending on the local balance between acids and $\mathrm{NH}_{3}$ (Jacob et al., 1986). Photochemical activity is reduced because of the cloud cover and low sun angle.

At Riverside, California (inset B of Fig. 1) radiation fogs form during the winter months. Samples were collected there during the winter of 
1986. Persistent temperature inversions over the Los Angeles basin trap emissions near the ground. Prevailing winds that blow from the coast are funneled through the Riverside area during the day; nocturnal land breezes recycle the air mass back toward the coast. Very high pollutant levels are observed under these conditions. In addition to urban emissions from urban Los Angeles and Orange County, the Riverside area is affected by numerous dairy feedlots located in Chino, a few $\mathrm{km}$ to the west. These feedlots are a major source of $\mathrm{NH}_{3}$ in the Los Angeles basin (Russell and Cass, 1986) and could also emit some organic compounds. Details of the sampling conditions at Riverside and complete results are given elsewhere (Munger, 1989).

Stratus clouds are a frequent occurrence along the California coast. Temperature inversions associated with subsidence in the Pacific High cap the mixed layer. As noted above, sea/land breeze cycles recirculate emissions and secondary pollutants (Cass and Shair, 1984). Local emission sources include numerous offshore oil platforms and the population centers along the coastal plain. Transport of emissions from Los Angeles to the Santa Barbara Channel has been observed (Shair et al., 1982). In addition, extensive areas are covered with chaparral and forest outside the immediate urban areas; these are potential sources for natural hydrocarbons. Clouds at 3 sites along the Santa Barbara Channel coast were sampled in July and August of 1986 (see Fig. 1). Samples were collected from two elevations on Laguna Peak, which is at the southeastern end of the channel. The upper site is identified as Laguna Peak; the lower site is identified as Laguna Road. The Ventura site was located on a hill overlooking the city, while the third site, Casitas Pass, was located at the head of a valley. A complete description of the sampling conditions and the inorganic composition of the samples is given elsewhere (Munger, 1989).

Intercepted stratus clouds were sampled from San Pedro Hill overlooking Los Angeles Harbor (see inset B of Fig. 1) during June and July 1987. This site is affected at times by nearby refineries, as well as by the overall mix of emissions from throughout the Los Angeles basin. A complete description of the sampling conditions and the inorganic composition of the samples is given elsewhere (Munger, 1989).
The San Joaquin Valley samples were collected with a Rotating Arm Collector (Jacob et al., 1984). The remainder of the samples were collected with a Caltech Active Strand Collector (Daube et al., 1987). Although the CASC does not isolate the collected droplets from the air stream as quickly as the RAC, it collects the entire droplet size spectrum effectively, generates larger sample volumes, and its operation is automated (Daube et al., 1987). Side-by-side comparison of the two collectors does not indicate any bias in $\mathrm{CH}_{2} \mathrm{O}$ concentrations (Collett, unpublished data). If, as we will attempt to show, dissolved carboxylic acids and carbonyls in clouds and fog are in equilibrium with the gas phase, then their concentrations will not depend on droplet size unless the $\mathrm{pH}$ or $\mathrm{S}(\mathrm{IV})$ concentrations of the droplets is size dependent.

In order to assess the droplet-size dependence of fog and cloud chemical composition a sizefractionating inlet was constructed for the CASC. A series of teflon rods at the mouth of the inlet collect the larger droplets. This $50 \%$ collection efficiency based on droplet diameter is $16 \mu \mathrm{m}$. The remaining droplets penetrate to the strands and are collected there. A series of cloudwater samples were collected at San Pedro Hill using this inlet on the morning of 15 July 1987.

No gas-phase concentrations with which to compare the aqueous-phase concentrations are available because the method used in our field program ( $\mathrm{NaOH}$ impregnated filters) has been shown to produce an artifact (Keene, personal communication).

Formaldehyde in fog and cloud samples was determined by the Nash method (Nash, 1953; Reitz, 1980). The reagent mixture was added to the sample in the field to stabilize the $\mathrm{CH}_{2} \mathrm{O}$ as 3,5-diacetyl-1,4-dihydrolutidine (DDL). lodine was used in most cases to eliminate $S(I V)$, which complexes with $\mathrm{CH}_{2} \mathrm{O}$ (Smith and Erhrdt, 1975). In order to assess the efficacy of the Nash method at determining S(IV)-bound formaldehyde standards were prepared with $\mathrm{NaCH}_{2} \mathrm{OHSO}_{3}$ as well as $37 \% \mathrm{CH}_{2} \mathrm{O}$ solution. Recovery of $\mathrm{CH}_{2} \mathrm{O}$ from the sulfonate standards was $90-100 \%$ compared to the $\mathrm{CH}_{2} \mathrm{O}$ standard. The San Pedro Hill samples were analyzed according to Dong and Dasgupta's (1987) modification of the Nash method for use with an autoanalyzer. This procedure employs addition of 
S(IV) to aliquots of sample shortly after collection to stabilize $\mathrm{CH}_{2} \mathrm{O}$ as the sulfonate salt (Boyce and Hoffmann, 1984). Immediately before analysis, the samples were treated with strong base and $\mathrm{H}_{2} \mathrm{O}_{2}$ to release $\mathrm{CH}_{2} \mathrm{O}$.

Chloroform was added to aliquots of sample shortly after collection to retard decomposition of the carboxylic acids (Keene and Galloway, 1984). Samples were analyzed by Ion Exclusion Chromatography on a Dionex 2020i Ion Chromatograph. The San Joaquin Valley samples were analyzed with a Dionex ICE anion separator column and $\mathrm{Ag}^{+}$resin packed-bed suppressor. Subsequent samples were analyzed using the Dionex HPICE AS1 column preceded by an MPIC (uncharged resin) guard column. The guard column was installed to protect the separator column from nonpolar material in the samples. The eluents used in all cases were $\mathrm{HCl}$ at 1-5 mM concentration. A Dionex ICE AMMS suppressor was tested, but high baselines and a limited lifetime made it impractical for these analyses. Parallel analysis by normal ion chromatography using $2 \mathrm{mM} \mathrm{Na} \mathrm{B}_{4} \mathrm{O}_{7}$ as eluent gave equivalent results for $\mathrm{HCOOH}$ concentrations, but acetate coeluted under these conditions with propionate and lactate and perhaps other acids. In addition to formate and acetate, which are reported here, several other acids were frequently observed in the chromatograms. These peaks have been tentatively identified as lactate or glyoxylate and pyruvate.

\section{Results and discussion}

The concentration range and mean value for each sampling site are given for formate, acetate, and formaldehyde in Tables 2-4. The vapor equivalent is the product of the aqueous-phase concentration and the liquid water content of the cloud (fog), which is estimated from the collection rate. Equilibrium partial pressures were calculated from the measured concentration and $\mathrm{pH}$ using Henry's Law and dissociation constants adjusted to a typical temperature for the sample group.

Among the San Joaquin Valley sites McKittrick consistently had the lowest carboxylic acid concentrations (see Fig. 2). Concentrations at Bakersfield were quite variable; the
Table 2. Formate concentrations

\begin{tabular}{|c|c|c|c|c|}
\hline \multirow[b]{2}{*}{ Site } & \multicolumn{4}{|c|}{ Measured aqueous phase $(\mu \mathbf{M})$} \\
\hline & $\mathbf{N}$ & Min & $\operatorname{Max}$ & Avg \\
\hline Bakersfield & 6 & 40 & 169 & 77 \\
\hline McKittrick & 26 & 0 & 56 & 21 \\
\hline Visalia & 11 & 40 & 187 & 71 \\
\hline Buttonwillow & 2 & 133 & 157 & 145 \\
\hline Riverside & 11 & 106 & 1517 & 627 \\
\hline Casitas Pass & 25 & 16 & 58 & 27 \\
\hline Ventura & 16 & 31 & 96 & 60 \\
\hline Laguna Peak & 16 & 24 & 103 & 42 \\
\hline Laguna Road & 18 & 21 & 74 & 39 \\
\hline \multirow[t]{2}{*}{ San Pedro Hill } & 21 & 12 & 43 & 20 \\
\hline & \multicolumn{4}{|c|}{ Vapor equivalent (ppb)* } \\
\hline Site & $\mathbf{N}$ & Min & $\operatorname{Max}$ & Avg \\
\hline Bakersfield & 6 & 0.081 & 0.234 & 0.133 \\
\hline McKittrick & 26 & 0.000 & 0.164 & 0.071 \\
\hline Visalia & 11 & 0.036 & 0.348 & 0.112 \\
\hline Buttonwillow & 2 & 0.209 & 0.442 & 0.326 \\
\hline Riverside & 11 & 0.224 & 2.486 & 0.885 \\
\hline Casitas Pass & 25 & 0.032 & 0.145 & 0.081 \\
\hline Ventura & 16 & 0.078 & 0.203 & 0.126 \\
\hline Laguna Peak & 16 & 0.075 & 0.337 & 0.193 \\
\hline Laguna Road & 18 & 0.048 & 0.130 & 0.087 \\
\hline \multirow[t]{2}{*}{ San Pedro Hill } & 19 & 0.005 & 0.152 & 0.076 \\
\hline & \multicolumn{4}{|c|}{ Equilibrium partial pressure (ppb) } \\
\hline Site & $\mathbf{N}$ & Min & $\operatorname{Max}$ & Avg \\
\hline Bakersfield & 6 & 0.001 & 0.75 & 0.16 \\
\hline McKittrick & 26 & 0 & 1.4 & 0.41 \\
\hline Visalia & 11 & 0.001 & 0.11 & 0.013 \\
\hline Buttonwillow & 2 & 0.20 & 0.56 & 0.38 \\
\hline Riverside & 11 & 1.55 & 33 & 9.3 \\
\hline Casitas Pass & 25 & 0.64 & 5.8 & 1.5 \\
\hline Ventura & 17 & 0.0 & 12 & 6.7 \\
\hline Laguna Peak & 16 & 2.7 & 12 & 4.8 \\
\hline Laguna Road & 18 & 2.0 & 9.7 & 4.5 \\
\hline San Pedro Hill & 21 & 0.79 & 4.5 & 1.8 \\
\hline
\end{tabular}

* Vapor equivalent $=C_{\mathrm{aq}} L R T$, where $L$ is the liquid water content $\left(\mathrm{g} \mathrm{m}^{-3}\right), R$ is the gas constant and $T$ is ${ }^{\circ} \mathrm{K}$.

most highly concentrated samples there had large excesses of acetate relative to formate. At Buttonwillow both the formate concentrations and formate/acetate ratio were fairly high. Visalia, on the other hand had an excess of acetate. Higher levels of $\mathrm{CH}_{3} \mathrm{COO}^{-}$may indicate 
Table 3. Formate concentrations

\begin{tabular}{lrrrr}
\hline & \multicolumn{4}{c}{ Measured aqueous phase $(\mu \mathrm{M})$} \\
\cline { 2 - 5 } Site & $\mathrm{N}$ & Min & Max & Avg \\
\hline Bakersfield & 6 & 0 & 244 & 83 \\
McKittrick & 25 & 0 & 28 & 3 \\
Visalia & 11 & 35 & 187 & 86 \\
Buttonwillow & 2 & 47 & 74 & 60 \\
Riverside & 11 & 56 & 581 & 245 \\
Casitas Pass & 25 & 4 & 14 & 10 \\
Ventura & 17 & 3 & 173 & 32 \\
Laguna Peak & 16 & 12 & 44 & 18 \\
Laguna Road & 17 & 7 & 34 & 15 \\
San Pedro Hill & 21 & 6 & 31 & 10 \\
\hline
\end{tabular}

\begin{tabular}{lrlll}
\hline & \multicolumn{4}{c}{ Vapor equivalent (ppb)* } \\
\cline { 2 - 5 } Site & $\mathrm{N}$ & Min & Max & Avg \\
\hline Bakersfield & 6 & 0.048 & 0.498 & 0.185 \\
McKittrick & 25 & 0.0 & 0.046 & 0.007 \\
Visalia & 11 & 0.032 & 0.348 & 0.134 \\
Buttonwillow & 2 & 0.074 & 0.208 & 0.141 \\
Riverside & 11 & 0.108 & 1.026 & 0.353 \\
Casitas Pass & 25 & 0.010 & 0.057 & 0.031 \\
Ventura & 17 & 0.009 & 0.360 & 0.068 \\
Laguna Peak & 16 & 0.046 & 0.121 & 0.082 \\
Laguna Road & 18 & 0.000 & 0.101 & 0.034 \\
San Pedro Hill & 19 & 0.002 & 0.079 & 0.036 \\
\hline
\end{tabular}

\begin{tabular}{lclll}
\hline & \multicolumn{3}{c}{ Equilibrium partial pressure (ppb) } \\
\cline { 2 - 5 } Site & $\mathrm{N}$ & Min & Max & Avg \\
\hline Bakersfield & 6 & 0 & 0.33 & 0.11 \\
McKittrick & 26 & 0 & 0.44 & 0.05 \\
Visalia & 11 & 0.003 & 0.37 & 0.05 \\
Buttonwillow & 2 & 0.21 & 0.64 & 0.42 \\
Riverside & 11 & 1.6 & 8.5 & 4.0 \\
Casitas Pass & 25 & 0.20 & 0.74 & 0.44 \\
Ventura & 17 & 0.18 & 9.15 & 1.67 \\
Laguna Peak & 16 & 0.59 & 2.3 & 0.96 \\
Laguna Road & 17 & 0.38 & 1.8 & 0.76 \\
San Pedro Hill & 21 & 0.27 & 1.6 & 0.52 \\
\hline
\end{tabular}

* Vapor equivalent $=C_{\mathrm{aq}} L R T$, where $L$ is the liquid water content $\left(\mathrm{g} \mathrm{m}^{-3}\right), R$ is the gas constant and $T$ is ${ }^{\circ} \mathrm{K}$.

a greater contribution from fresh emissions, which are enriched in $\mathrm{CH}_{3} \mathrm{COOH}$ (Talbot et al., 1988).

McKittrick had the lowest formaldehyde concentrations, followed by Visalia (see Fig. 3). Most of the samples from these two sites had $<50 \mu \mathrm{M}$
Table 4. Formaldehyde concentrations

\begin{tabular}{lrrrr}
\hline & \multicolumn{3}{c}{ Measured aqueous phase $(\mu \mathrm{M})$} \\
\cline { 2 - 5 } Site & N & Min & Max & Avg \\
\hline Bakersfield & 16 & 27 & 498 & 168 \\
McKittrick & 49 & 6 & 93 & 26 \\
Visalia & 15 & 18 & 65 & 31 \\
Buttonwillow & 6 & 61 & 115 & 88 \\
Riverside & 16 & 65 & 384 & 236 \\
Casitas Pass & 30 & 3 & 13 & 7.8 \\
Ventura & 32 & 7 & 18 & 13 \\
Laguna Peak & 15 & 7 & 32 & 17 \\
Laguna Road & 20 & 11 & 15 & 13 \\
San Pedro Hill & 20 & 5 & 38 & 13 \\
\end{tabular}

\begin{tabular}{lrccc}
\hline & \multicolumn{4}{c}{ Vapor equivalent (ppb)* } \\
\cline { 2 - 5 } Site & $\mathrm{N}$ & Min & Max & Avg \\
\hline Bakersfield & 16 & 0.035 & 1.24 & 0.281 \\
McKittrick & 49 & 0.009 & 0.180 & 0.069 \\
Visalia & 15 & 0.017 & 0.074 & 0.039 \\
Buttonwillow & 6 & 0.065 & 0.324 & 0.142 \\
Riverside & 16 & 0.090 & 0.793 & 0.378 \\
Casitas Pass & 29 & 0.007 & 0.046 & 0.025 \\
Ventura & 32 & 0.005 & 0.071 & 0.031 \\
Laguna Peak & 15 & 0.022 & 0.166 & 0.080 \\
Laguna Road & 20 & 0.011 & 0.064 & 0.033 \\
San Pedro Hill & 18 & 0.013 & 0.193 & 0.051 \\
\hline
\end{tabular}

\begin{tabular}{lcccc}
\hline & \multicolumn{4}{c}{ Equilibrium partial pressure (ppb) } \\
\cline { 2 - 5 } Site & $\mathrm{N}$ & Min & Max & Avg \\
\hline Bakersfield & 16 & 1.6 & 30 & 10 \\
McKittrick & 49 & 0.36 & 5.6 & 1.6 \\
Visalia & 15 & 1.1 & 3.9 & 1.9 \\
Buttonwillow & 6 & 3.7 & 6.9 & 5.3 \\
Riverside & 16 & 12.8 & 30 & 18 \\
Casitas Pass & 30 & 0.31 & 1.2 & 0.78 \\
Ventura & 32 & 0.75 & 1.8 & 1.3 \\
Laguna Peak & 15 & 0.72 & 3.2 & 1.7 \\
Laguna Road & 20 & 1.1 & 1.5 & 1.3 \\
San Pedro Hill & 20 & 0.53 & 3.8 & 1.3 \\
\hline
\end{tabular}

* Vapor equivalent $=C_{\mathrm{aq}} L R T$, where $L$ is the liquid water content $\left(\mathrm{g} \mathrm{m}^{-3}\right), R$ is the gas constant and $T$ is ${ }^{\circ} \mathrm{K}$.

$\left[\mathrm{CH}_{2} \mathrm{O}\right]$. The Buttonwillow samples fell in the range $70-120 \mu \mathrm{M}$. The highest concentrations of formaldehyde (up to $500 \mu \mathrm{M}$ ) were in samples from Bakersfield.

Because the solubility of carbonyls and carboxylic acids is a function of temperature and 


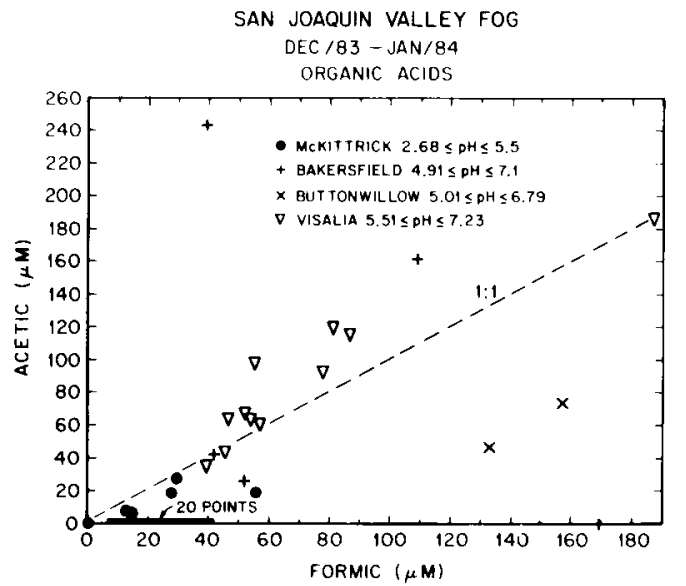

Fig. 2. Formic and acetic acid concentrations in San Joaquin Valley fog samples. The range of $\mathrm{pH}$ in the samples is noted in the symbol legend. Data from Jacob et al. (1986).

$\mathrm{pH}$ (for the acids) it may be misleading to compare aqueous-phase concentrations among samples with different $\mathrm{pH}$ or collected at different temperatures. We have normalized our results with respect to temperature and $\mathrm{pH}$ by calculating the equilibrium partial pressures. The total carboxylic acid in the aqueous phase (vapor equivalent) is comparable to or larger than the equilibrium partial pressure at Visalia, Bakersfield, and Buttonwillow. At these sites it is likely that most of the available carboxylic acid has been scavenged by the fog. Only at McKittrick, which had consistently acidic fog, was the aqueous phase concentration small compared to the calculated equilibrium. If it were at equilibrium, McKittrick would actually have had the highest total formic acid. The equilibrium concentrations of acetic acid were comparable among the sites. The observed concentration patterns were related to the proximity to sources. McKittrick and Bakersfield are adjacent to oil fields, or major urban areas. The major hydrocarbon sources, which are precursors to carboxylic acids and formaldehyde, are well to the south of Visalia. Formaldehyde and total carboxylic acid levels were low there. Bakersfield, being the largest urban area, has the highest $\mathrm{CH}_{2} \mathrm{O}$ concentrations. The inorganic anions, $\mathrm{NO}_{3}^{-}$and $\mathrm{SO}_{4}^{2-}$, which are derived from combustion sources, were also highest at Bakersfield. The formation of the $\mathrm{S}(\mathrm{IV})-\mathrm{CH}_{2} \mathrm{O}$ adduct, hydroxymethanesulfonate, also contributes to

\section{SAN JOAQUIN VALLEY FOG \\ DEC / 83 - JAN/84 \\ FORMALDEHYDE DISTRIBUTION}

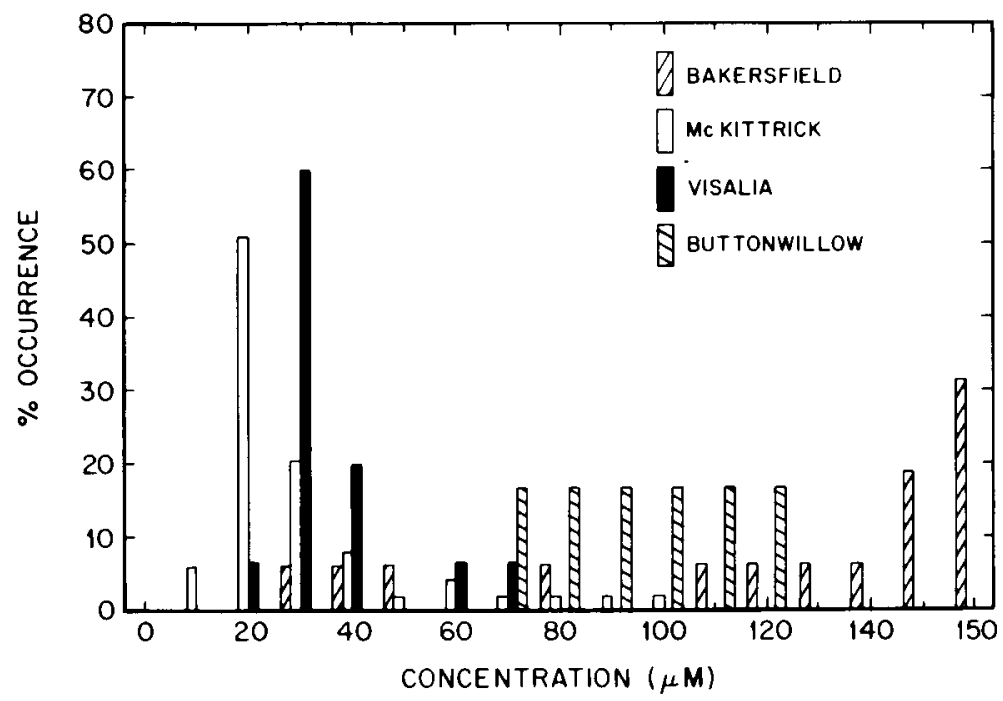

Fig. 3. Distribution of $\mathrm{CH}_{2} \mathrm{O}$ concentrations in San Joaquin Valley fog samples. Data from Jacob et al. (1986). 


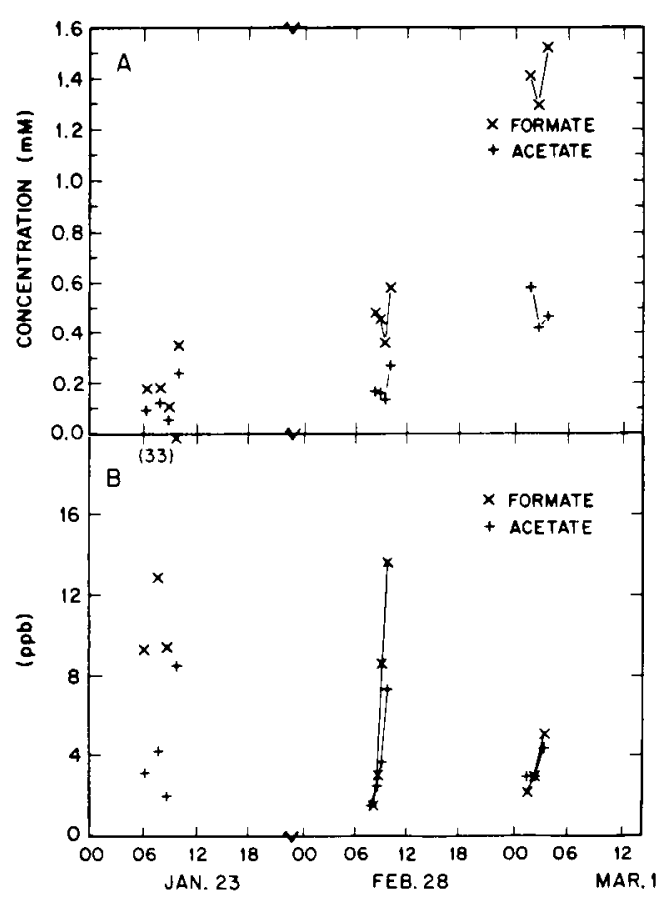

Fig. 4. Formate and acetate concentrations versus time in Riverside, CA fog samples collected during the winter of 1986. Points not connected by lines were not consecutive samples. Panel A shows the measured aqueous concentrations. Panel B shows the calculated equilibrium partial pressures at $15^{\circ} \mathrm{C}$.

RIVERSIDE FOGWATER

$\mathrm{CH}_{2} \mathrm{O}$

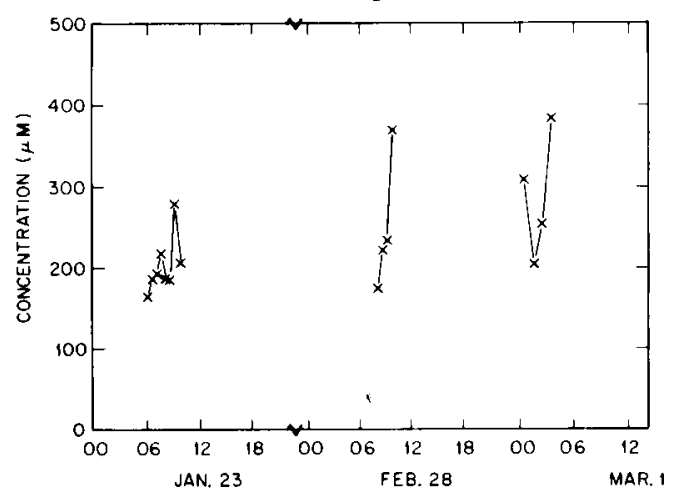

Fig. 5. Formaldehyde concentrations versus time in Riverside, CA fogwater samples collected during the winter of 1986. high $\mathrm{CH}_{2} \mathrm{O}$ concentrations at Bakersfield (Munger et al., 1984, 1986).

Formic and acetic acid concentrations in the Riverside fogwater samples were extremely high (see Fig. 4A). Formic acid exceeded $1000 \mu \mathrm{M}$ during the 3 January 1986 event; acetic acid was around $500 \mu \mathrm{M}$. These values are a factor of 10 higher than the values reported by Kawamura and Kaplan (1984) for a single fog sample collected in Los Angeles. Formaldehyde levels (Fig. 5) ranged from 150 to near $400 \mu \mathrm{M}$; the variation within an event was as great as between events. Similar concentrations of $\mathrm{CH}_{2} \mathrm{O}$ have been observed in Los Angeles coastal fogs (Munger et al., 1983). The maximum $\mathrm{CH}_{2} \mathrm{O}$ concentration observed in Los Angeles fog and mist by Grosjean and Wright (1983) or Steinberg and Kaplan (1984) using the DNPH derivative method was $75 \mu \mathrm{M}$. Glyoxal and methylglyoxal were also found in the Riverside fogwater samples at concentrations comparable to the $\mathrm{CH}_{2} \mathrm{O}$ (Munger, 1989). High concentrations of organic carbon species in the Riverside fogwater are not surprising considering its location downwind of the Los Angeles urban area, with its heavy concentration of vehicle emissions and active photochemical smog chemistry. The concentration increases at the end of the fog events coincide with morning traffic and wind reversal, which would advect fresh emissions to the site. For comparison, the range of $\mathrm{NH}_{4}^{+}, \mathrm{NO}_{3}^{-}$and $\mathrm{SO}_{4}^{2-}$ was 8.3-26 mM, 6.1-29 mM, and 1.4-6.2 $\mathrm{mM}$, respectively (Munger, 1989).

The large differences in aqueous-phase carboxylic acid concentrations between the three events are due to the fogwater acidity. The range of equilibrium partial pressures of the acids for each event overlap (Fig. 4B). In all but the highest $\mathrm{pH}$ samples the aqueous-phase acid was much less than the potential equilibrium partial pressure. Formate always exceeded acetate in these samples, although the magnitude of the excess increased with concentration.

Figs. 6 and 7 indicate that the distributions of formate, acetate, and formaldehyde concentrations at the four Santa Barbara Channel sites have considerable overlap. Because these samples were routinely acidic the aqueous phase was a small fraction of the total acid present. Casitas Pass, which had the lowest concentrations of inorganic components, also had the lowest 


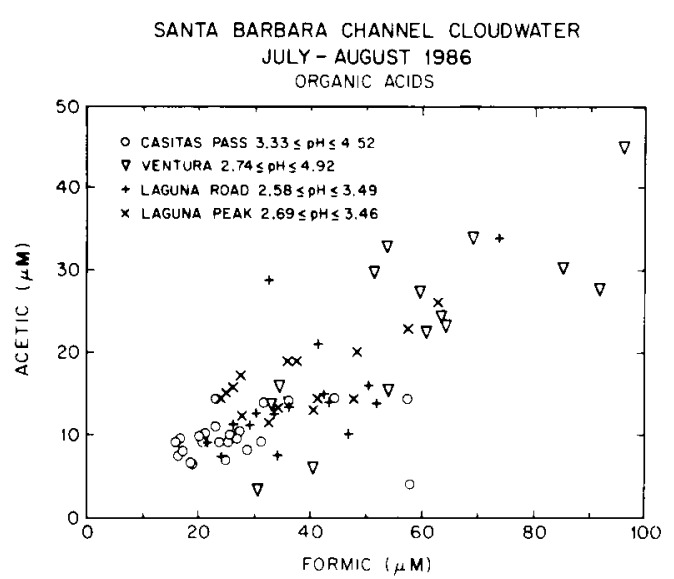

Fig. 6. Formate and acetate concentrations in intercepted stratus cloud samples from four sites along the Santa Barbara Channel coast. The range of $\mathrm{pH}$ in each set of samples is indicated in the symbol legend.

organic concentrations. Because of its location at the head of a valley it may be isolated from the major emission sources and is affected more by cleaner, upper level air, entrained in drainage flows from the surrounding mountains. Two features distinguished these samples from the San Joaquin Valley and Riverside samples. Formate consistently exceeded acetate and the formaldehyde concentrations were relatively low.

Fig. 8 shows an apparently linear relationship between formate and acetate at the San Pedro Hill site. The line fit through the data has a slope of about 0.5 (i.e., formate/acetate $=2$ ). This corresponds to a $\mathrm{HCOOH}_{\mathrm{T}} / \mathrm{CH}_{3} \mathrm{COOH}_{\mathrm{T}}$ ratio that is smaller than the average of 2.4 reported for marine rain samples (Keene and Galloway, 1987), but larger than the value of $\approx 1.5$ reported by Talbot et al. (1988) for precipitation during the growing season at Hampton, VA. Because of the acidity in these samples, the equilibrium partial pressures were much greater than the vapor equivalent of the aqueous phase. Carboxylic acid concentrations at San Pedro Hill were generally less than at our other sites. Formaldehyde levels at San Pedro Hill (Fig. 9) were comparable to the stratus cloud samples from the Santa Barbara Channel area.

The size-fractionated samples from San Pedro Hill were collected after several hours of the

\section{SANTA BARBARA CHANNEL CLOUDWATER 1986} FORMALDEHYDE DISTRIBUTION

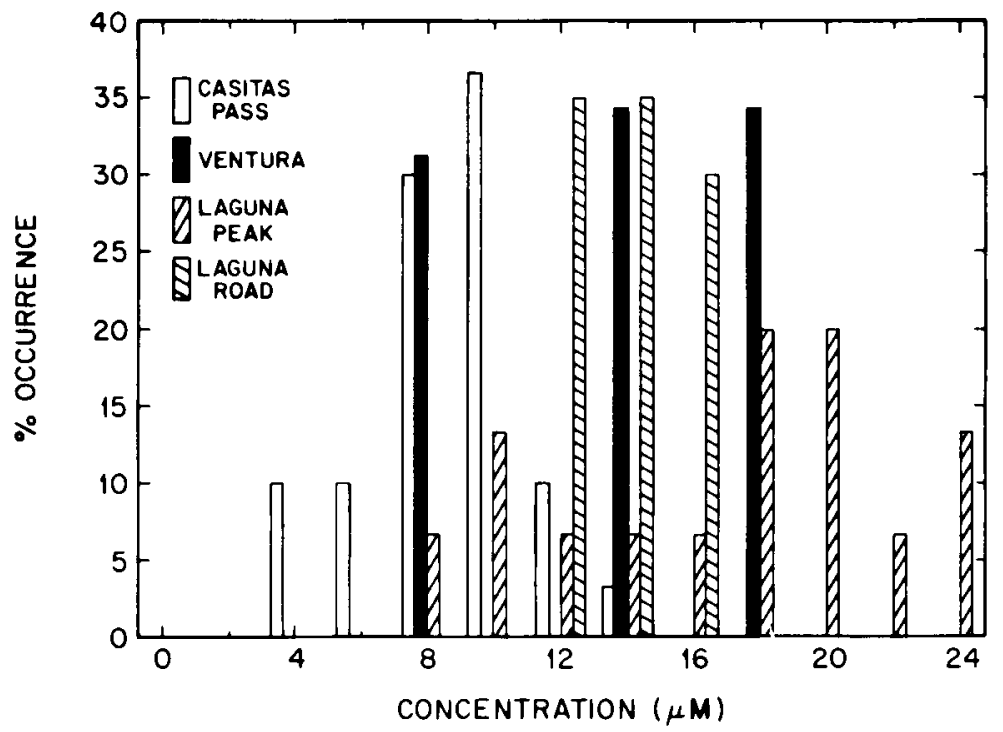

Fig. 7. Distribution of $\mathrm{CH}_{2} \mathrm{O}$ concentrations in intercepted stratus cloud samples from four sites along the Santa Barbara Channel coast. 


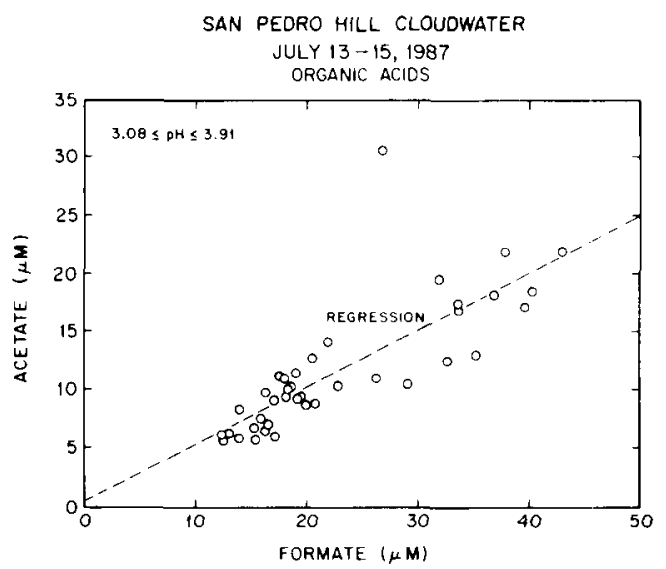

Fig. 8. Formate and acetate concentrations in samples of intercepted stratus clouds on San Pedro Hill. The range of sample $\mathrm{pH}$ is indicated at the upper left of the figure.

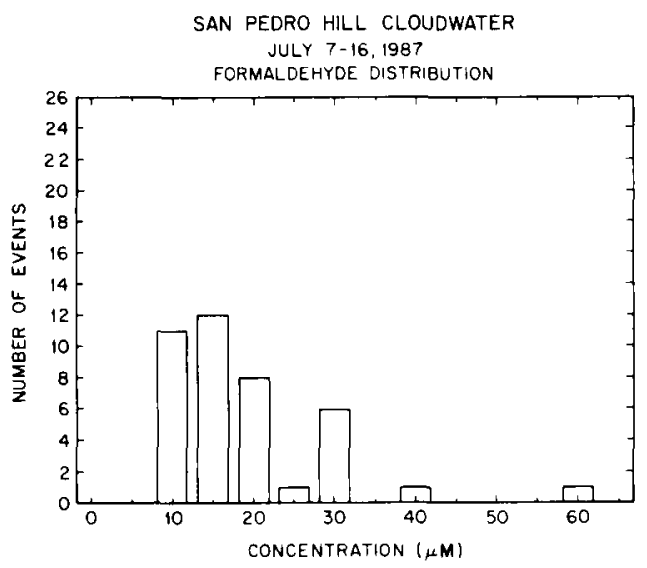

Fig. 9. Distribution of $\mathrm{CH}_{2} \mathrm{O}$ concentrations in intercepted stratus cloud samples from San Pedro Hill.

presence of cloud. Cloud intercepted the hilltop around sunset the previous evening and continued throughout the night. The size-fractionated sampling began at 0400 and continued until the cloud was too thin to sample. Drizzle, falling intermittently from 0630 to 1000 , contributed to the coarse fraction of the cloudwater.

Comparison of the inorganic components suggests that size-dependent differences in the

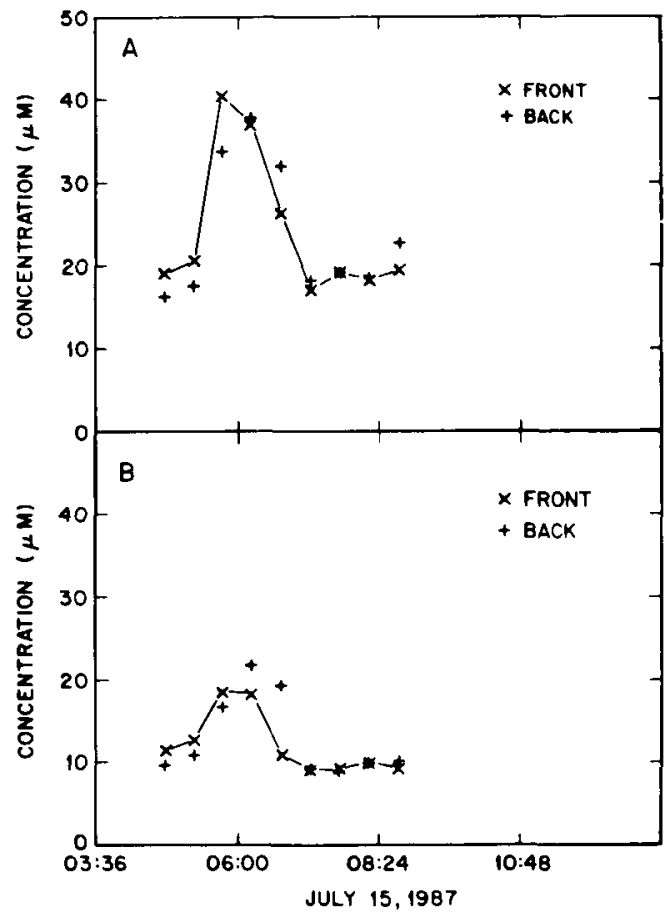

Fig. 10. Formate (A) and acetate (B) concentrations in size-fractionated cloudwater samples from San Pedro Hill. Large droplets are collected in the front fraction; small droplets are collected in the back fraction.

composition of the precursor aerosol are retained in the droplets (Munger, 1989). The large drops had higher concentrations of soil dust and sea salt components, which would reside in the larger aerosol. The small drops had higher levels of $\mathrm{SO}_{4}^{2-}, \mathrm{NH}_{4}^{+}$, and $\mathrm{H}^{+}$, which would derive from the smaller secondary aerosol. Components that exist partly in the gas phase $\left(\mathrm{NO}_{3}^{-}\right.$and $\left.\mathrm{Cl}^{-}\right)$did not appear to be size segregated. The difference in $\mathrm{pH}$ was small however. Fig. 10 shows that there is little difference in the carboxylic acid concentrations of the two cloudwater fractions, which would be expected if the cloud were in equilibrium with the surrounding air. The equilibrium partial pressures of each fraction are comparable. Over the cloudwater $\mathrm{pH}$ range of 3 to 3.6 most of the carboxylic acid will be in the gas phase. Even during periods of drizzle when some of the large droplets could have originated from near the top of the cloud, equilibrium appears to be maintained. The $\mathrm{CH}_{2} \mathrm{O}$ concen- 


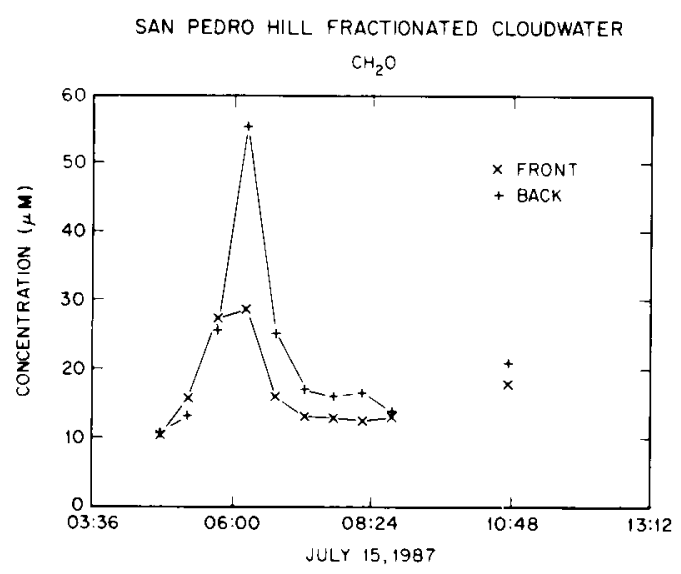

Fig. 11. Formaldehyde concentrations in the sizefractionated cloudwater samples from San Pedro Hill. Large droplets are collected in the front fraction; small droplets are collected in the back fraction.

trations (Fig. 11) in the initial fractionated samples are equivalent, which is consistent with equilibrium considerations. Beginning at 0530 there was a spike in $\left[\mathrm{CH}_{2} \mathrm{O}\right],[\mathrm{HCOOH}]$, and $\left[\mathrm{CH}_{3} \mathrm{COOH}\right]$ as well as the major inorganic ions, that could not be attributed to a drop in liquid water content. The carboxylic acids appear to maintain their equilibrium; however, the smalldroplet fraction has a much higher $\left[\mathrm{CH}_{2} \mathrm{O}\right]$ during this spike. The difference decays away over the next 3 hours. The sharpness of this pulse suggests passage of a plume or a major wind shift The $\mathrm{CH}_{2} \mathrm{O}$ data imply that the precursor nuclei for the smaller droplets contain $\mathrm{CH}_{2} \mathrm{O}$ that is not in equilibrium with the gas phase. The presence of the S(IV) adduct, hydroxymethanesulfonate (HMSA) (Munger et al., 1984), could account for this. At the observed $\mathrm{pH}$ of $\simeq 3.5$ the kinetics of HMSA dissociation would be quite slow (Boyce and Hoffmann, 1984), thus HMSA in the precursor aerosol would be retained in the droplet where it would be measured as $\mathrm{CH}_{2} \mathrm{O}$. Preliminary measurements of S(IV) and HMSA itself in these samples are consistent with this explanation.

Some of the cloud (fog) events exhibited a concave concentration versus time profile for the carboxylic acids. The variation over time was greatest for $\mathrm{HCOOH} ; \mathrm{CH}_{3} \mathrm{COOH}$ changed only slightly. Formaldehyde was often constant over the same periods. In previous studies we have observed this pattern in the concentrations of inorganic ions and attributed it to dilution and concentration as liquid water content varies over the life of the cloud (fog). Carboxylic acid concentrations should be independent of liquid water content if they are in equilibrium. However, we cannot determine from these data whether the concentrations are responding to changes in liquid water content or to other factors that affect both total organic concentration and liquid water content. Many of the clouds (fogs) dissipate after sunrise. Photochemical production, fresh emissions and increased mixing would all contribute to higher concentrations as the droplets were evaporating.

\section{Summary and conclusions}

High concentrations of carboxylic acid were observed in fogs and clouds where $\mathrm{pH}$ was high or near sources of precursor hydrocarbons. Riverside, where both conditions are met for some events, had the highest carboxylic acid concentrations seen in southern California. The apparent lower concentrations of carboxylic acid in stratus clouds at San Pedro Hill relative to the Santa Barbara Channel sites is surprising if urban pollution is a major source of carboxylic acids. The elevation of the sampling sites and meteorological conditions were similar for both sets of samples. A more detailed analysis of air mass histories will be required to interpret these data. Proximity to sources alone did not account for the $\mathrm{CH}_{2} \mathrm{O}$ concentrations in fog and cloud. Bakersfield, which is adjacent to major combustion sources, had high concentrations of $\mathrm{CH}_{2} \mathrm{O}$ in fogwater, but clouds at San Pedro Hill, which is affected by Los Angeles air pollution, did not. The shallower mixed layer, weaker insolation, and higher $\mathrm{SO}_{2}$ concentrations (which would support sulfonate formation) at Bakersfield are factors that would account for higher $\left[\mathrm{CH}_{2} \mathrm{O}\right]$. Furthermore, the Bakersfield samples were collected at ground level, whereas, the San Pedro sampling site was on a $450 \mathrm{~m}$ hill. The hilltop location and night time sampling at San Pedro Hill may account for the apparent low $\mathrm{P}_{\mathrm{CH}_{2} \mathrm{O}}$ compared to previous measurements of gas-phase $\mathrm{CH}_{2} \mathrm{O}$ in Los Angeles (Grosjean, 1982). In general $[\mathrm{HCOOH}]$ exceeded $\left[\mathrm{CH}_{3} \mathrm{COOH}\right]$ in these fog and cloudwater samples, which agrees 
with the trends noted by Keene and Galloway (1986). The San Joaquin Valley and high pH Riverside fog samples, which were the most strongly affected by feedlot emissions, were notable exceptions. If this latter observation is not due simply to coincidence, it suggests that animal wastes may be a source of $\mathrm{CH}_{3} \mathrm{COOH}$ or that destruction of $\mathrm{HCOO}^{-}$is accelerated in high pH droplets as suggested by Jacob (1986). Alternatively, ground level fogs may be more strongly influenced by direct anthropogenic emissions, which are enriched in $\mathrm{CH}_{3} \mathrm{COOH}$ relative to $\mathrm{HCOOH}$ (Talbot et al., 1988).

\section{Acknowledgements}

This research was supported by a contract with the California Air Resources Board (contract \# A4-075-32). We thank the California Air Resources Board, Avenue Cable TV of Ventura, the US Navy, the Federal Aviation Administration and Dr. R. Musselman of Univ. Calif. Riverside for the permission to use their facilities as sampling sites. This work would not have been possible without the field and laboratory assistance of C. Choy, G. Gibb, W. Chong, and A. Kaloustian.

\section{REFERENCES}

Betterton, E., Erel, Y. and Hoffmann, M. R. 1988. Aldehyde-bisulfite adducts: Prediction of some of their thermodynamic and kinetic properties. Environ. Sci. Technol. 22, 3011-3020.

Boyce, S. D. and Hoffmann, M. R. 1984. Kinetics and mechanism of the formation of hydroxymethanesulfonic acid at low pH. J. Phys. Chem. 88, 47404746.

Carlier, P., Hannachi, H. and Mouvier, G. 1986. The chemistry of carbonyl compounds in the atmosphere-A Review. Atmos. Environ. 20, 2079-2099.

Cass, G. R. and Shair, F. H. 1984. Sulfate accumulation in a sea breeze/land breeze circulation system. $J$. Geophys. Res. 89, 1429-1438.

Chameides, W. L. 1984. The photochemistry of a remote marine stratiform cloud. J. Geophys. Res. 89, 4739-4755.

Daube, B. C. Jr., Flagan, R. C. and Hoffmann, M. R. 1987. Active Cloudwater Collector. United States Patent \#4,697,462, 6 October 1987.

Dong, S. and Dasgupta, P. K. 1987. Fast flourimetric flow injection analysis of formaldehyde in atmospheric water. Environ. Sci. Technol. 21, 581-588.

Finlayson-Pitts, B. J. and Pitts, J. N., Jr. 1986. Atmospheric chemistry: fundamentals and experimental techniques. New York: John Wiley, 1098 pp.

Galloway, J. N., Likens, G. E., Keene, W. C. and Miller, J. M. 1982. The composition of precipitation in remote areas of the world. J. Geophys. Res. 87, 8771-8786.

Graedel, T. E., Hawkins, D. T. and Claxton, L. D. 1986. Atmospheric chemical compounds: sources, occurrence, and bioassay. New York: Academic Press, 732 pp.

Grosjean, D. 1982. Formaldehyde and other carbonyls in Los Angeles ambient air. Environ. Sci. Technol. 16, 254-262.

Grosjean, D. and Wright, B. 1983. Carbonyls in urban fog, ice fog, and cloudwater and rainwater. Atmos. Environ. 17, 2093-2096
Jacob, D. J. 1986. The chemistry of $\mathrm{OH}$ in remote clouds and its role in the production of formic acid and peroxymonosulfate. J. Geophys. Res. 91, 9807-9826.

Jacob, D. J., Wang, R.-F. T. and Flagan, R. C. 1984. Fogwater collector design and characterization. Environ. Sci. Technol. 18, 827-833.

Jacob, D. J., Munger, J. W., Waldman, J. M. and Hoffmann, M. R. 1986. The $\mathrm{H}_{2} \mathrm{SO}_{4}-\mathrm{HNO}_{3}-\mathrm{NH}_{3}$ system at high humidities and in fogs: $\mathrm{I}$. Spatial and temporal patterns in the San Joaquin Valley of California. J. Geophys. Res. 9I, 1073-1088.

Jacob, D. J. and Wofsy, S. C. 1988. Photochemical production of carboxylic acids in a clean continental atmosphere. In: Acid deposition processes at high elevation sites (ed. H. M. Dunsworth). Hingham, Mass: D. Reidel (in press).

Kawamura, K., Ng, L. L. and Kaplan, I. R. 1985. Determination of organic acids $\left(C_{1}-C_{10}\right)$ in the atmosphere, motor exhausts, and engine oils. Environ. Sci. Technol. 19, 1082-1086.

Kawamura, K. and Kaplan, I. R. 1984. Capillary gas chromatography determination of volatile organic acids in rain and fog samples. Anal. Chem. 56, 16161620.

Keene, W. C. and Galloway, J. N. 1984. Organic acidity in precipitation of North America. Atmos. Environ. 18, 2491-2497.

Keene, W. C. and Galloway, J. N. 1986. Considerations regarding sources for formic and acetic acids in the troposphere. J. Geophys. Res. 91, 14466-14474.

Keene, W. C., Galloway, J. N. and Holden, J. D. 1983. Measurement of weak organic acidity in precipitation from remote areas of the world. J. Geophys. Res. 88, 5122-5130.

Likens, G. E., Edgerton, E. S. and Galloway, J. N. 1983. The composition and deposition of organic carbon in precipitation. Tellus 35, 16-24.

Liljestrand, H. M. and Morgan, J. J. 1981. Spatial variations of acid precipitation in southern California. Environ. Sci. Technol. 15, 333-338. 
Munger, J. W. 1989. Chemical composition of fogs and clouds in southern California. Ph.D. Thesis, California Institute of Technology, Pasadena, CA.

Munger, J. W., Jacob, D. J. and Hoffmann, M. R. 1984. The occurrence of bisulfite-aldehyde adducts in fog- and cloudwater. J. Atmos. Chem. 1, 335-350.

Munger, J. W., Tiller, C. T. and Hoffmann, M. R. 1986. Determination of hydroxymethanesulfonate in fog water. Science $231,247-249$.

Nash, T. 1953. The colorimetric estimation of formaldehyde by means of the Hantszch reaction. Biochem. J. 55, 416-421.

National Research Council, 1981. Formaldehyde and other aldehydes. Washington, DC: National Academy Press, 340 pp.

Olson, T. M. and Hoffmann, M. R. 1988. The formation kinetics, mechanism, and thermodynamics of glyoxylic acid-S(IV) adducts. J. Phys. Chem. 92, 4246-4253.

Reitz, E. B. 1980. The stabilization of small concentrations of formaldehyde in aqueous solutions. Analyt. Lett. 13, 1073-1084.

Rogozen, M. B., Maldonado, G., Grosjean, D., Shochet, A. and Rapoport, R. 1984. Formaldehyde: A survey of airborne concentrations and sources. Final Report to California Air Resources Board. Sacramento, CA, $311 \mathrm{pp}$.
Russell, A. G. and Cass, G. R. 1986. Verification of a mathematical model for aerosol nitrate and nitric acid formation and its use for control measure evaluation. Atmos. Environ. 18, 1815-1817.

Schwartz, S. E. and Freiberg, J. E. 1981. Mass-transport limitation to the rate of reaction of gases in liquid droplets: Application to oxidation of $\mathrm{SO}_{2}$ in aqueous solutions. Atmos. Environ. 15, 1129-1144.

Seinfeld, J. H. 1986. Atmospheric chemistry and physics of air pollution. New York: John Wiley, 738 pp.

Shair, F. H., Sasaki, E. J., Carlan, D. E., Cass, G. R., Goodin, W. R., Edinger, J. G. and Schacher, G. E. 1982. Transport and dispersion of airborne pollutants associated with the land breeze-sea breeze system. Atmos. Environ. 16, 2043-2053.

Smith, R. V. and Erhardt, P. W. 1975. Nash determination for formaldehyde in the presence of bisulfite. Anal. Chem. 47, 2462-2454.

Steinberg, S. and Kaplan, I. R. 1984. The determination of low molecular weight aldehydes in rain, fog, and mist by reversed phase liquid chromatography of the 2,4-dinitrophenyl hydrazone derivatives. Intern. J. Environ. Anal. Chem. 18, 253-266.

Talbot, R. W., Beecher, K. M., Harriss, R. C. and Cofer, W. R., III. 1988. Atmospheric geochemistry of formic and acetic acids at a mid-latitude temperate site. J. Geophys. Res. 93, 1638-1652. 